\title{
2020 International Year of the Nurse and Midwife and International Nurses' Day
}

\author{
Carol M. Baldwin, PhD, RN, CHTP, CT, AHN-BC, FAAN \\ Edson College of Nursing \& Health Innovation \\ Arizona State University \\ Phoenix, AZ USA
}

\section{Barbara M. Dossey, PhD, RN, AHN-BC, FAAN, HWNC-BC \\ Nightingale Initiative for Global Health (NIGH) \\ Washington, DC USA}

The World Health Organization (WHO) designated 2020 as the International Year of the Nurse and Midwife to acknowledge the contributions of nurses and midwives in promoting the health and welfare of populations across the globe. This recognition is in concert with the $200^{\text {th }}$ anniversary of the birth of Florence Nightingale. Although nurses and midwives make up over half the world's health care workforce, the WHO estimates that 2020 will see a shortage of 9 million nurses $(1,2)$. International Nurses' Week begins May $6^{\text {th }}$ and culminates on May $12^{\text {th }}$, International Nurses Day, the anniversary of Nightingale's birth with hopes of bringing greater re, cognition nurses play in local to global health.

Defying expected Victorian norms for women born to well-connected, affluent British families in the middle of the nineteenth century, Florence Nightingale chose the art and science of nursing over marriage. "Nightingale" is synonymous with the foundation of professional nursing, as well as her dedicated service as a manager and trainer of nurses during the Crimean War.

Florence Nightingale's influence, however, encompasses so much more than establishing nursing education. Military and field medicine, epidemiology, early prefabricated hospitals, hospital supervision, community and public health, health policy, establishment of nursing schools and infirmaries, early pioneering in the concept of medical tourism, as well as social reform for women and all sections of society have benefitted from her groundbreaking achievements. Her work continues. The Nightingale Initiative for Global Health (NIGH), for example, fosters Nightingale's activities grounded in social and environmental justice, preventive medicine, and holistic health from the local to global levels $(3,4)$.

A keen observer of conditions that lead to poor health, Nightingale wrote extensively regarding sanitary reform. Her Notes on Nursing emphasized frequent handwashing that presaged the hygiene required during the current Covid-19 pandemic (5). Nightingale was the first woman admitted to the London Statistical Society (5). She became a member of the American Statistical Association (6). She was the first nurse to conduct and use research. Nightingale showed that physical and social factors 
influenced health, and that quality of care can be improved through careful data collection, visual displays that used her original "Polar-Area Diagram," critical thinking, and practice based on evidence (7).

Florence Nightingale's legacy endures in the face of the Covid-19 pandemic. It was announced on 24 March 2020 that the new "Nightingale Hospital" would be set up at the ExCel conference centre in East London to provide support for up to 4,000 patients with Covid-19 (8). On 3 April 2020, within two weeks of the announcement, the NHS

Nightingale Hospital was officially opened by HRH Prince Charles as a coronavirus field hospital. In his remarks, Prince Charles stated, "Florence Nightingale, the lady with the lamp, brought hope and healing to thousands in their darkest hour. In this dark time this place will be a shining light" (9).

The Southwest Journal of Pulmonary and Critical Care congratulates and values the many legatees of Florence Nightingale in this 2020 International Year of the Nurse--the nurses and midwives across the globe for their unwavering dedication to education, research, practice and policy, as well as our valued interprofessional collaborations in promoting health and preventing disease.

\section{References}

1. World Health Organization. Year of the Nurse and the Midwife 2020. Accessed 1 May $2020 \mathrm{from} \mathrm{https://www.who.int/news-room/campaigns/year-of-the-nurse-and-}$ the-midwife-2020

2. Jakel P. WHO's International Year of the Nurse and Midwife. Accessed 1 May 2020 from https://www.oncnursingnews.com/publications/oncology-nurse/2020/april2020/2020-whos-international-year-of-the-nurse-and-the-midwife

3. Beck DM, Dossey BM. In Nightingale's footsteps - individual to global: From nurse coaches to environmental and civil society activists. Creative Nursing: A Journal of Values, Issues, Experience and Collaboration, 2019;25(3):1-6.

4. Dossey BM, Rosa WE, Beck DM. Nursing and the sustainable development goals: From Nightingale to now. American Journal of Nursing, 2019;119(5):40-45.

5. Bates, R. Florence Nightingale: A pioneer of handwashing and hygiene for health. Accessed 3 May 2020 from https://theconversation.com/florence-nightingale-apioneer-of-hand-washing-and-hygiene-for-health-134270

6. Columbia Mailman School of Public Health, Healthcare Policy. Florence Nightingale was an epidemiologist too. Accessed 4 May 2020 from https://www.mailman.columbia.edu/public-health-now/news/florence-nightingalewas-epidemiologist-too

7. Baldwin CM, Schultz AA, Barrere CC. (2016) 'Evidence-based practice', in Dossey BM \& Keegan L., Holistic nursing: A handbook for practice. Burlington, MA: Jones \& Bartlett, p. 639. 
8. NHS England Website. Accessed 1 May 2020 from New NHS Nightingale Hospital To Fight Coronavirus

9. Evening Standard. NHS Nightingale officially opened by Prince Charles as coronavirus field hospital becomes world's largest critical care unit. Accessed 2 May 2020 from https://www.standard.co.uk/news/health/nhs-nightingale-coronavirus-fieldhospital-open-prince-charles-a4405796.html

\title{
2020 Año Internacional de la Enfermera y Partera y el Día Internacional de la Enfermera
}

\author{
Carol M. Baldwin, PhD, RN, CHTP, CT, AHN-BC, FAAN \\ Edson College of Nursing \& Health Innovation \\ Arizona State University \\ Phoenix, AZ USA
}

Barbara M. Dossey, PhD, RN, AHN-BC, FAAN, HWNC-BC

Nightingale Initiative for Global Health (NIGH)

Washington, DC USA

La Organización Mundial de la Salud (OMS) designó 2020 como el Año Internacional de la Enfermera y la Partera para reconocer las contribuciones de las enfermeras y parteras en la promoción de la salud y el bienestar de las poblaciones de todo el mundo. Este reconocimiento está en concierto con el bicentenario del nacimiento de Florence Nightingale. Si bien las enfermeras y las parteras representan más de la mitad de la fuerza laboral mundial de atención de la salud, la OMS estima que en 2020 habrá una escasez de 9 millones de enfermeras $(1,2)$. La Semana Internacional de Enfermeras comienza el 6 de mayo y culmina el 12 de mayo, Día Internacional de las Enfermeras, el aniversario del nacimiento de Nightingale con la esperanza de brindar un mayor reconocimiento a las enfermeras en la salud local y mundial.

Desafiando las normas victorianas esperadas para las mujeres nacidas de familias británicas acomodadas y bien conectadas a mediados del siglo XIX, Florence Nightingale eligió el arte y la ciencia de la enfermería en lugar del matrimonio. "Nightingale" es sinónimo de la base de la enfermería profesional, así como su servicio dedicado como gerente y formadora de enfermeras durante la Guerra de Crimea.

La influencia de Florence Nightingale, sin embargo, abarca mucho más que establecer una educación en enfermería. Medicina militar y de campo, epidemiología, hospitales prefabricados tempranos, supervisión hospitalaria, salud comunitaria y pública, política de salud, establecimiento de escuelas de enfermería y enfermerías, pioneros tempranos en el concepto de turismo médico, así como reforma social para las mujeres y todos los sectores de la sociedad se han beneficiado de sus logros innovadores. Su trabajo continúa. La Nightingale Initiative for Global Health (NIGH), por ejemplo, fomenta las actividades de Nightingale basadas en la justicia social y ambiental, la medicina preventiva y la salud holística desde el nivel local hasta el global $(3,4)$. 
Un observador entusiasta de las condiciones que conducen a la mala salud, Nightingale escribió ampliamente sobre la reforma sanitaria. Sus Notas sobre Enfermería enfatizaban el lavado frecuente de manos que presagiaba la higiene requerida durante la actual pandemia de Covid-19 (5). Nightingale fue la primera mujer admitida en la Sociedad Estadística de Londres (5). Se convirtió en miembro de la Asociación Americana de Estadística (6). Fue la primera enfermera para realizar y utilizar investigaciones. Nightingale demostró que los factores físicos y sociales influyeron en la salud, y que la calidad de la atención se puede mejorar mediante una cuidadosa recolección de datos, exhibiciones visuales que utilizaron su "diagrama de área polar" original, pensamiento crítico y práctica basada en evidencia (7).

El legado de Florence Nightingale perdura ante la pandemia de Covid-19. Se anunció el 24 de marzo de 2020 que el nuevo "Hospital Nightingale" se establecería en el centro de conferencias ExCel en el este de Londres para brindar apoyo a hasta 4,000 pacientes con Covid-19 (8). El 3 de abril de 2020, dentro de las dos semanas posteriores al anuncio, El "NHS Nightingale Hospital" fue inaugurado oficialmente por el Príncipe Carlos como un hospital de campaña de coronavirus. En sus comentarios, el Príncipe Carlos declaró: "Florence Nightingale, la dama de la lámpara, trajo esperanza y sanación a miles en su hora más oscura. En este tiempo oscuro este lugar será una luz brillante" (9).

The Southwest Journal of Pulmonary and Critical Care felicita y valora a los muchos legatarios de Florence Nightingale en este Año Internacional de la Enfermera 2020: las enfermeras y parteras de todo el mundo por su inquebrantable dedicación a la educación, la investigación, la práctica y la política, así como a nuestras valiosas colaboraciones interprofesionales en la promoción de la salud y la prevención de enfermedades.

\section{Referencias}

1. World Health Organization. Year of the Nurse and the Midwife 2020. Accessed 1 May 2020 from https://www.who.int/news-room/campaigns/year-of-the-nurse-andthe-midwife-2020

2. Jakel P. WHO's International Year of the Nurse and Midwife. Accessed 1 May 2020 from https://www.oncnursingnews.com/publications/oncology-nurse/2020/april2020/2020-whos-international-year-of-the-nurse-and-the-midwife

3. Beck DM, Dossey BM. In Nightingale's footsteps - individual to global: From nurse coaches to environmental and civil society activists. Creative Nursing: A Journal of Values, Issues, Experience and Collaboration, 2019;25(3):1-6.

4. Dossey BM, Rosa WE, Beck DM. Nursing and the sustainable development goals: From Nightingale to now. American Journal of Nursing, 2019;119(5):40-45.

5. Bates, R. Florence Nightingale: A pioneer of handwashing and hygiene for health. Accessed 3 May 2020 from https://theconversation.com/florence-nightingale-apioneer-of-hand-washing-and-hygiene-for-health-134270 
6. Columbia Mailman School of Public Health, Healthcare Policy. Florence Nightingale was an epidemiologist too. Accessed 4 May 2020 from

https://www.mailman.columbia.edu/public-health-now/news/florence-nightingalewas-epidemiologist-too

7. Baldwin CM, Schultz AA, Barrere CC. (2016) 'Evidence-based practice', in Dossey BM \& Keegan L., Holistic nursing: A handbook for practice. Burlington, MA: Jones \& Bartlett, p. 639.

8. NHS England Website. Accessed 1 May 2020 from New NHS Nightingale Hospital To Fight Coronavirus

9. Evening Standard. NHS Nightingale officially opened by Prince Charles as coronavirus field hospital becomes world's largest critical care unit. Accessed 2 May 2020 from https://www.standard.co.uk/news/health/nhs-nightingale-coronavirus-fieldhospital-open-prince-charles-a4405796.html 